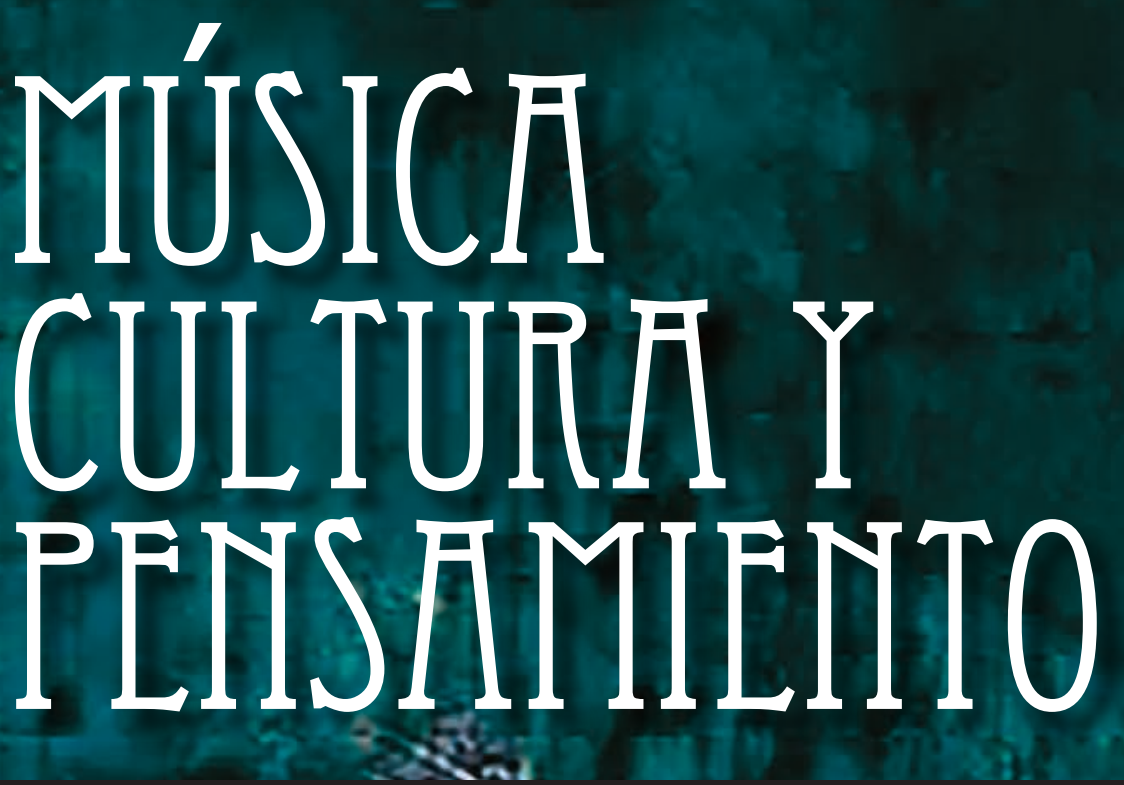

Revista de investigación de la Facultad de Educación y Artes del Conservatorio del Tolima
VOL. VII N.` 7 - Enero 2018
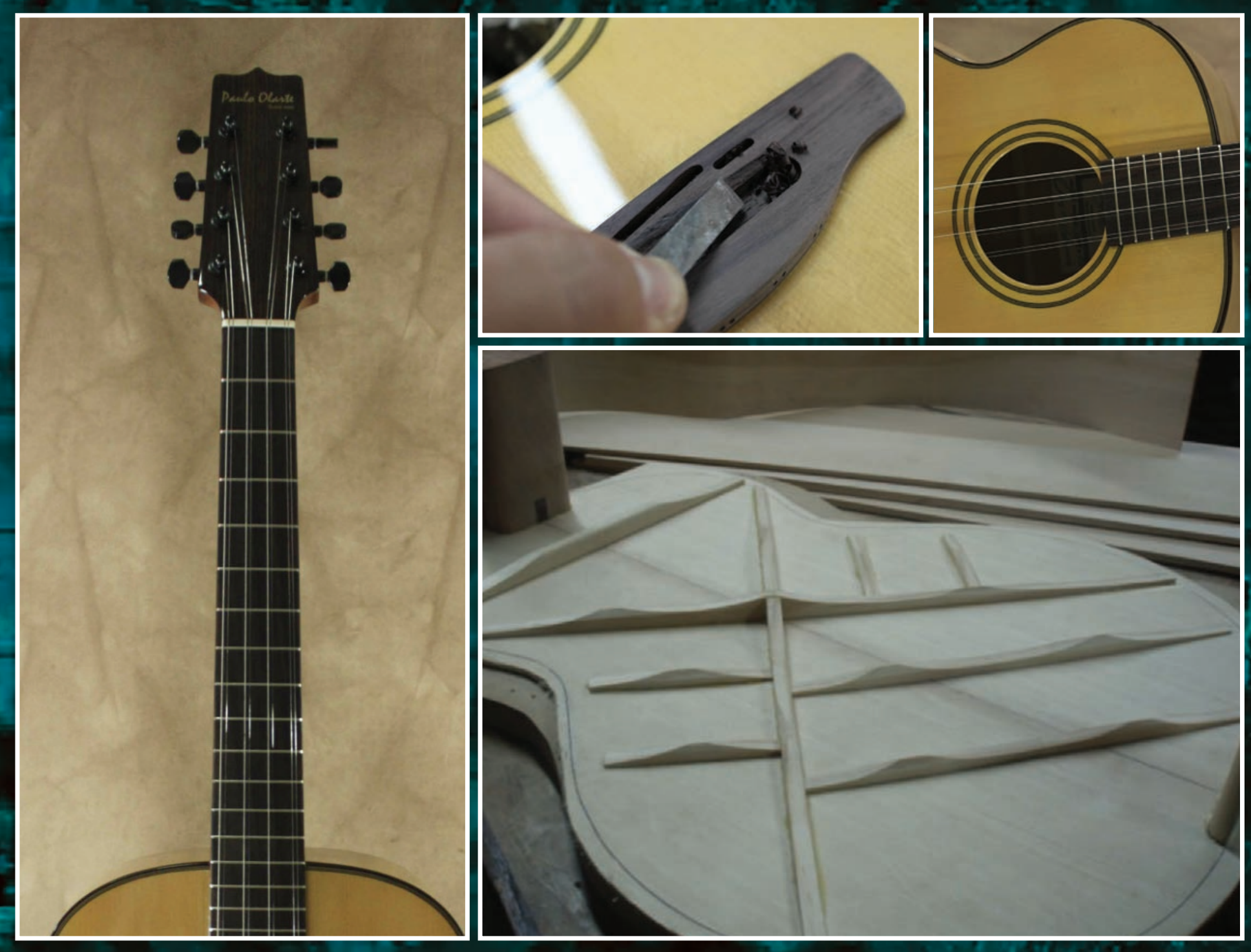


\section{Arte y música como apropiación social del conocimiento en el \\ proyecto regional Aprociencia} Art and music as social appropriation of knowledge in the regional project Aprociencia

Para citar este artículo/To reference this article Galindo, H. (2017). Arte y música como apropiación social del conocimiento en el proyecto regional Aprociencia. Música, Cultura y Pensamiento 7 (7), 18-35.

Por: Humberto Galindo Palma ${ }^{1}$

Artículo de reflexión ${ }^{2}$

Recibido: 10 de noviembre del 2016

Aceptado: 12 de junio del 2017

1 Docente e investigador. Magíster en Musicología de la Universidad Nacional de Colombia. Autor de libros y estudios de género en música sobre compositores regionales del Tolima. Director de la colección de instrumentos musicales Mundo Sonoro y de la Fundación Cantatierra. Profesor asociado y coordinador de investigación y editor de la revista Música, Cultura y Pensamiento del Conservatorio del Tolima.

2 Este artículo se deriva de los informes elaborados para la consultoría y evaluación técnica de contenidos de arte y cultura para el proyecto "Implementación de una estrategia de apropiación social del conocimiento basada en innovación para la infancia, la adolescencia y la juventud del departamento del Tolima, Aprociencia", formulado en el 2014 por la Universidad del Tolima para la creación de un centro de ciencia y parque interactivo con cobertura departamental. Dicho proyecto contó con el aval y financiamiento del programa de Ciencia y Tecnología Colciencias, la Gobernación del Tolima, y la asesoría del Conservatorio del Tolima. Para el análisis diagnóstico de los contenidos mencionados, se tomaron como referencia los productos entregados en la primera fase del proyecto, pertenecientes a los informes del equipo técnico conformado para el diseño de los temas para el componente Arte y Música de los autores Andrea Hernández Guayara, Óscar Díaz y Armor le Bihan.

\section{Resumen}

El proyecto Aprociencia, formulado en el 2014 por un equipo de investigadores de la Universidad del Tolima, surge de la necesidad de creación de espacios interactivos dirigidos a la infancia, la adolescencia y la juventud del departamento del Tolima con coberturas local y regional, en el marco de la Política Nacional de Fomento a la Investigación y la Innovación Colombia Construye y Siembra Futuro. Este artículo evalúa los contenidos de arte y música diseñados dentro de la propuesta, a la luz de los referentes de museos interactivos y centro de ciencia de cuarta generación en que se ha concebido su implementación.

Palabras clave: museo interactivo, centro de ciencia, arte y música.

\section{Abstract}

The Aprociencia project, developed in 2014 by a team of researchers from the University of Tolima, arises from the need to create interactive spaces aimed at children, adolescents and youth in the department of Tolima with local and regional coverage, and falls within the National Policy framework for the Promotion of Research and Innovation Colombia Construye y Siembra Futuro (Build Colombia \& Sow the Future). This article evaluates the art and music content designed within the proposal, in the light of the interactive museums and the fourth generation science center from which the project implementation has been conceived.

Keywords: interactive museum, science center, art and music. 


\section{Introducción}

El proyecto Aprociencia fue formulado en el 2014 por un equipo de Nacional de Fomento a la Investigación y la Innovación Colombia Construye y Siembra Futuro, la cual propende por la apropiación del uso del conocimiento para la modernización del sistema productivo y aumento de la competitividad del país con equidad (Colciencias, 2008; Conpes 3527, 3582). El proyecto partió de la necesidad de creación de espacios interactivos dirigidos a la infancia, la adolescencia y la juventud del departamento del Tolima con cobertura local y regional. A través de sus tres estrategias de innovación Parque Interactivo, Maletas Didácticas y Aulas Interactivas, Aprociencia integra las temáticas de música y arte; bioquímica, agua y minería; astronomía, robótica; agroindustria; matemáticas y física. Este artículo presenta los resultados del proceso de evaluación diagnóstica del diseño de contenidos museográficos de las áreas de música y arte, formulados en la primera fase del proyecto para su perfeccionamiento e implementación dentro de estándares de pertinencia y calidad concebidos para el proyecto, especialmente al considerar que las entidades museales y centros de innovación desempeñan un papel importante no solo en la preservación del patrimonio representado en sus colecciones, sino también en su responsabilidad de darle nuevos sentidos y significados para sus públicos, mediante dispositivos e innovación que conviertan al observador en un participante (Casalins y Miranda, 2012).

\section{Hacia una cultura científica en la educación}

La promoción de la cultura científica y la técnica, la divulgación de ciencias y el apoyo a la educación son principios propios de todo museo o centro de ciencia. Para estos fines, dichos centros desarrollan un tipo particular de educación basada en procesos que incorporan la enseñanza, la información y el entretenimiento de manera integrada y diferente a la de instituciones educativas convencionales. Uno de los aspectos que aportan mayor relevancia a los proyectos de museos y centros de ciencia actuales es la interactividad, cualidad que surge de manera privilegiada entre los museos universitarios donde se busca "poner al usuario en la piel del científico" o en condición de percibir "emociones científicas". Desde esta condición inicial se plantea el modelo "glocal" como la posibilidad de articular el conocimiento universal con la realidad de cada lugar al brindarles a los visitantes una interactividad manual, mental y emocional a partir de referentes culturales propios (Tagüeña, Sánchez y Reynoso, 2006).

Las posibilidades de hacer efectivas las experiencias creativas del saber han Ilevado a replantear el papel de los museos en las sociedades contemporáneas, como un entorno de múltiples reflexiones donde se permite la negociación y el surgimiento de nuevo conocimiento (Braendholt y Thorek, 2013). La distinción entre las entidades museales y los centros de ciencia se establece desde los enfoques y momentos que han marcado la evolución de colecciones con fines culturales y científicos. Así, los museos clásicos de artes y ciencias naturales, muchos de los cuales surgieron en ámbitos universitarios, se consideran de primera generación, por el enfoque expositivo-taxonómico de sus colecciones y de ilustración pasiva, sin permitir ninguna interacción al visitante. La segunda generación está representada por los primeros museos de ciencia que con la exhibición de aparatos y mecanismos en funcionamiento, inducen al visitante a la acción mediante demostraciones y actividades que estimulan el contacto con los elementos expuestos. La tercera generación corresponde a aquellos centros de ciencia que trascienden el énfasis en los objetos para desarrollar exposiciones sobre ideas o fenómenos en los que el centro de atención es la curiosidad del visitante y su capacidad de interactuar con las colecciones. Allí toma relevancia la experiencia lúdica del usuario siendo su principal característica la "intractividad". La cuarta generación define los centros de ciencia que han surgido en el 
siglo xxı con un claro propósito por la innovación y popularización de los últimos avances científicos y tecnológicos, diferenciándose de los museos tradicionales conservacionistas. El papel participativo del visitante en este tipo de centros plantea como característica un reto a su creatividad confrontándolo en la resolución de problemas del entorno (Lozano, 2005, p. 159; McManus, 1992).

Independientemente del contenido o generación a la que pertenezca una entidad museal o centro de ciencia, es una tendencia internacional actual la apropiación de buenas prácticas y la migración hacia una nueva museología mediada por los últimos avances de las NTIC. La adopción de estas herramientas obedece en primer lugar a la demanda misma de los usuarios nativos digitales que en su mayoría componen el público objetivo de dichas entidades. Por otro lado, la conformación de redes de colaboración entre la comunidad cultural y científica internacional ha acelerado los procesos en la democratización del conocimiento, la investigación y la generación de patentes sobre el uso social de los últimos avances tecnológicos, cuyo destino final de transmisión al público está implícito en los museos y centros de ciencia contemporáneos, cuya instancia internacional es el ICOM, entidad de la cual emana el Código Deontológico, al que se deben acoger dichas entidades en cumplimiento de sus propósitos misionales. Al asumir dicho código, no solo se está garantizando la existencia de los proyectos museales dentro de las leyes internacionales de protección y uso de patrimonio natural, cultural y científico, sino que se ingresa al circuito mundial de este tipo de entidades, aceptando el seguimiento y certificación por parte del ente rector en la filosofía universal que los rige: "Los museos tienen contraídas obligaciones especiales para con la sociedad por lo que respecta a la protección, accesibilidad e interpretación de los testimonios esenciales que han acopiado y conservado en sus colecciones" (ICOM, 2013). Por lo anterior, la membresía a redes internacionales afines a los enfoques de los centros de ciencia es una premisa que fortalece la innovación, la competitividad y el trabajo colaborativo, dinamizando su visibilidad $y$ presencia en el universo de la oferta cultural y científica por fuera de su entorno local o nacional.

\section{Contexto colombiano de} la museología y su innovación

La historia museal colombiana ha sido eminentemente científica y se ha constituido a partir de expe- diciones botánicas, de desarrollos en ciencias naturales y medicina, así como de patrimonios históricos culturales de diversa índole, siendo el más antiguo el Museo Nacional de Colombia (1823). Durante la primera mitad del siglo $x x$ fueron creados por lo menos veinte museos nuevos hasta la constitución del Museo del Oro en 1939, otro de los referentes importantes para la nación. Para mediados de los años cincuenta, la expansión museal ya alcanzaba unas ochenta entidades distribuidas en las distintas regiones de Colombia, diferenciadas en sus temáticas y especialidades de tipo arqueológico, histórico y de artes, principalmente. Con la creación en 1984 del Museo de la Ciencia y el Juego de la Universidad Nacional de Colombia (Sistema de Patrimonio Cultural y Museos, 2007), se dio el inicio a un nuevo tipo de museos de tercera y cuarta generación, entre los que también se encuentran el Museo Interactivo EPM de Medellín y Maloka de Bogotá (López, s. f., p. 297). El surgimiento de más de trescientas entidades museales en todo el país motivó que la Ley General de Cultura de 1990 estableciera los primeros criterios para normativizar su funcionamiento, clasificación y políticas de acompañamiento a su gestión. La estrategia produjo la formalización de la Red Nacional de Museos que, a partir del Plan Estratégico 2001-2010, abrió las condiciones para que también se constituyeran redes departamentales de museos a escala regional con fines colaborativos $y$ de representación en las políticas públicas (López, s. f., pp. 301-306). Una de las tareas fundamentales de esta política gubernamental ha sido establecer las tipologías de dichas entidades de acuerdo con sus temáticas, origen de financiamiento y campo de proyección.

Tabla 1. Tipología de los museos

\section{Tipología temática}

- Museos de arte

o de Bellas Artes

- de Artes Aplicadas

o de Artes Populares

- Museos de antropología

o de Historia

- de Arqueología

- de Etnografía

- Museos de ciencias

- de Historia Natural

- Centros de ciencia

- Museos generales 


\section{Tipología por origen de recursos, ubicación y exposición \\ - Públicos: presupuesto de gobiernos centra- les, estatales o municipales. \\ - Privados o independientes: capitales priva- dos, estrategias propias de financiamiento, forman parte los museos corporativos o in- dustriales. \\ - Mixtos: presupuestos públicos y capitales privados. \\ - Universitarios: según la institución de ense- ñanza es público o privado, argumentos y colecciones afines a sus programas de estu- dios y las áreas de investigación. \\ - Comunitarios: apoyo del Estado en princi- pio, operación y mantenimiento dependen de cada comunidad.}

\section{Tipología / Área de influencia}

- Nacionales: caracterizan la cultura de un país.

- Regionales: aspectos característicos de un área.

- Locales o comunitarios: valores culturales propios de una localidad.

- De sitio: explicar aspectos destacados del lugar donde residen.

Fuente: grupo de investigación en Interfaces gráficas de la Universidad Pontificia Bolivariana. http://www.upb.edu.co/portal/page? pageid=1054,41020768\&_dad=portal\&_schema=PORTAL UPB

Por otro lado, las acciones colaborativas latinoamericanas entre TIC y entidades museales como las presentadas recientemente en el III Encuentro Nacional y II Internacional de Comunidades Académicas (Rumbo, Bogotá, 12 y 13 de noviembre del 2015) plantean el desarrollo de la museografía actual: en Chile, a partir del trabajo en red para la democratización y el intercambio de contenidos entre auditorios, se viene trabajando la inclusión tecnológica de públicos utilizando drones como recurso para la interconexión simultánea entre distintas salas del país. Unida a esta experiencia, la existencia de la Red Latinoamericana de Museos y sus proyectos de narrativas en red multimodales permiten anticipar que el futuro de los museos es la educación (Lannes, 2015).

\section{La música como objeto de exhibición}

Los primeros trabajos científicos para el tratamiento y exhibición de la música corresponden en su orden al Symtagma Musicum (1619) de Michael Praetorius; la L'Harmonie Universelle (1637) del sacerdote y cien- tífico Marin Marsenne y al Gabinetto Armónico (1723) de Filippo Bonanni, cuyos aportes han sido fundamentales para consolidar la musicología actual en el campo de la organología asociada a los museos especializados y centros de estudio del sonido como el Institut de Recherche et Coordination Acoustique/ Musique (IRCAM) (Galindo, 2009). En el contexto colombiano son pocas las iniciativas que se pueden referenciar en torno a la museología especializada en la música. Si bien el tema de los instrumentos musicales es transversal a los museos de tipo histórico o antropológico, de forma especializada solo se cuentan actualmente cuatro entidades en el país, correspondientes a la Colección de instrumentos José Ignacio Perdomo de la Biblioteca Luis Ángel Arango (Bogotá), el Museo Organológico de la Universidad Nacional de Colombia (Bogotá) y las colecciones Alfonso Viña Calderón de la Universidad de Ibagué y Mundo Sonoro de la Fundación Cantatierra (Ibagué). Dichas entidades representan un patrimonio museográfico para la conservación, investigación y difusión de los instrumentos musicales con un enfoque etnográfico e histórico (Galindo, 2003).

Los avances de la era digital en el siglo xxı han impactado de manera importante el fenómeno de la música transformando los canales de acceso al usuario mediados por las TIC y que han dado origen a la industria de la música y el entretenimiento con la creación de dispositivos para su registro, producción y distribución masivos. De la misma manera, el desarrollo de nuevas vías de acceso al conocimiento como Internet, han abierto posibilidades a millones de usuarios en el mundo para conocer de primera mano las innovaciones de la música desde cualquier perspectiva. Tomando estos referentes, es claro que la música actualmente ocupa un lugar relevante en los campos de la innovación y que la socialización de dichos avances a la comunidad encuentran un lugar privilegiado en aquellos museos y centros de ciencia que la incorporen como tema de exhibición y experimentación con fines lúdico-científicos y culturales, entre los que se destaca el proyecto de parque temático interactivo musical Sama Sama (Rebolledo, 2015), que se estrenó en el 2012 en Tel Aviv y en noviembre del 2015 en Madrid, en el que participa un equipo de ingenieros y artistas entre los que se incluye el Circo del Sol.

\section{Entidades museales y centros de ciencia en el Tolima}

Aunque el Tolima cuenta en la actualidad con más de diez entidades museales, todavía no se tiene una 
cultura de museos consolidada en el departamento. El Museo Antropológico de la Universidad del Tolima fue fundado en 1967 como el primer museo universitario tolimense, adscrito a la Facultad de Ciencias Humanas y Artes, Departamento Ciencias Sociales y Jurídicas ${ }^{3}$. El Museo de Arte del Tolima, entidad mixta, ha venido liderando desde el 2011 la Red Departamental de Museos del Tolima que integra colecciones e iniciativas localizadas en Ibagué, Prado, Honda y Mariquita. Estas entidades desarrollan principalmente exposiciones de tipo histórico, arqueológico, de antigüedades, de instrumentos musicales y cuenta con dos parques naturales o jardines botánicos ${ }^{4}$. Sin otros referentes distintos a exposiciones itinerantes presentadas en Ibagué por el Observatorio de Ciencia y Tecnología e Innovación Codecty (Ibagué, 2014), la iniciativa del proyecto Aprociencia se vislumbra como la pionera en constituir un programa de características de parque interactivo o centro de ciencia para la región, que integra tanto el concepto científico como el patrimonio cultural en sus contenidos. Este debe reconocerse como un proyecto que nace desde el ámbito universitario, con financiamiento mixto del orden nacional, lo que amplía sus expectativas de impacto local y regional.

Las iniciativas particulares de las reconocidas familias ibaguereñas Sicard y Melendro a finales del siglo xix contribuyeron a consolidar la música y la formación artística que dio origen al Conservatorio del Tolima como una de las primeras instituciones de su tipo en el país (Villegas, 1962). Este valor cultural es un patrimonio social que incide directamente en la calidad de vida de los ciudadanos, al brindarles oportunidades de disfrute y conocimiento de su propia identidad regional. Ibagué ha sido reconocida como "capital musical" gracias a su tradición de más de un siglo fundada desde el Conservatorio del Tolima y proyectada a toda la región en múltiples procesos formativos y artísticos (Pardo, 1997). Por este antecedente se ha considerado la inclusión de la música y el arte dentro del proyecto Aprociencia, desde su concepción de centro de ciencia que aborda tanto la mirada científica como la cultural para la creación de sus contenidos y actividades, en coherencia con los antecedentes culturales de ciudad y de región, como uno los factores estratégicos de desarrollo

3 http://www.ut.edu.co/academico/index.php/institucional1/facultades-e-instituto-de-educacion-a-distancia/facultad-de-ciencias-humanas-y-artes/unidades-adscritas/museo-antropologico.

4 www.museodeartedeltolima.org. trazados dentro de la política gubernamental Visión Tolima $2025^{5}$.

\section{Referentes de análisis para el proyecto Aprociencia}

Para la evaluación diagnóstica del componente arte y música del proyecto Aprociencia se establecieron puntos de referencia que parten de modelos museográficos reconocidos dentro de la disciplina por su eficacia en la estructuración preliminar de todo proyecto expositivo y del diseño de sus contenidos y estrategias de implementación (Ministerio de Educación, Cultura y Deporte de España, s. f.). También se consideraron los instrumentos de medición y clasificación de proyectos museales establecidos por el Sistema de Información Museal Colombiano (SIMCO), los cuales tienen vigencia nacional y servirán como guía para la futura formalización del proyecto dentro de dicho sistema. El soporte para este diagnóstico corresponde al informe y anexos presentados por el equipo técnico del Conservatorio del Tolima vinculado al diseño del componente del proyecto (Hernández, 2015).

\section{Enfoque de guion museológico y museográfico}

Los contenidos temáticos de música y arte como ejes integradores en el diseño del proyecto Aprociencia corresponden a la concepción de un museo o centro de innovación de cuarta generación, puesto en marcha desde los espacios parque interactivo, maletas didácticas y aulas interactivas digitales. Dicho concepto encuentra afinidad con la tendencia actual de muchos centros de ciencia, en los que convergen miradas desde lo global como lo local del conocimiento, definidas mejor como el enfoque glocal.

[...] los museos se ven ahora ante la necesidad de considerar su impacto educativo a nivel local a largo plazo, para lo cual es fundamental tomar en cuenta su contexto social, económico y cultural local, pero siempre dentro del marco global (Reynoso, Sánchez y Tagüeña, 2005, p. 37).

El guion museológico del componente música y arte se fundamenta en las siguientes ideas fuerza para el visitante: 1) percibo y comprendo los fenómenos del sonido asociados a la acústica y a la música;

5 www.visiontolima2025.org. 
2) descubro y reconozco valores regionales musicales representativos del Tolima (creadores, repertorios, certámenes, patrimonio organológico); 3) descubro la memoria e historia cultural del Tolima y su lugar en la historia del país, y 4) percibo y experimento creativamente desde las artes plásticas y la música (Hernández, 2015). La manera como se articulan los conceptos en el desarrollo del montaje están sujetas a los tres contextos concebidos para el proyecto parque, maletas didácticas y software, a partir de los cuales se construye el guion museográfico respectivo. Por tratarse de un proyecto en fase inicial, el guion museográfico aún no puede ser expresado de manera definitiva y requiere de la reelaboración macro y micro de los programas del plan museal, antes de alcanzar su siguiente fase de implementación práctica. No obstante, en los componentes de arte y música ya elaborados es claro el énfasis de "interactividad" que orienta las actividades, así como el interés por comunicar el patrimonio histórico y cultural regional utilizando simultáneamente técnicas de la museografía clásica con herramientas de NTIC. En las siguientes tablas se sintetizan los aspectos diseñados hasta el momento sobre arte y música en cada uno de los espacios del parque interactivo.

Tabla 2. Diseño de contenidos de arte y música, proyecto Aprociencia

\begin{tabular}{|c|c|c|c|}
\hline \multicolumn{4}{|c|}{ Sala de Pensamiento } \\
\hline Actividad & Contenido temático & Mensaje & Ficha técnica \\
\hline Vibramúsica & $\begin{array}{l}\text { El mundo de sonidos: la natura- } \\
\text { leza, la industria, la ciudad. } \\
\text { Cada elemento vibrante produce } \\
\text { una sensación que nuestro oído } \\
\text { convierte en sonido. } \\
\text { El material sonoro constituye } \\
\text { la base fundamental de la mú- } \\
\text { sica. } \\
\text { Las vibraciones que capta el } \\
\text { oído, el fenómeno físico de las } \\
\text { ondas sonoras mecánicas. }\end{array}$ & $\begin{array}{l}\text { La música está } \\
\text { compuesta por ondas } \\
\text { sonoras que pueden } \\
\text { representarse en } \\
\text { diversos materiales } \\
\text { como arena, sal y aceite. }\end{array}$ & $\begin{array}{l}\text { Fenómeno acústico. } \\
\text { Incluye la participa- } \\
\text { ción de varios usua- } \\
\text { rios. } \\
\text { Requiere dispositivos } \\
\text { electrónicos como ge- } \\
\text { neradores de sonido y } \\
\text { parlantes. }\end{array}$ \\
\hline Espacio de DJ & $\begin{array}{l}\text { Los DJ (disc jockey). Los usuarios } \\
\text { podrán realizar diferentes téc- } \\
\text { nicas que utiliza el DJ como el } \\
\text { groove, el breakbeat y el remix. }\end{array}$ & $\begin{array}{l}\text { Cómo se realiza una } \\
\text { mezcla de música en la } \\
\text { radio. }\end{array}$ & $\begin{array}{l}\text { Actividad experimen- } \\
\text { tal sonora. }\end{array}$ \\
\hline
\end{tabular}

\begin{tabular}{|l|l|l|l|}
\hline \multicolumn{4}{|c|}{ Sala de la Cultura “Llevo en mí el folclor tolimense” } \\
\hline \multicolumn{1}{|c|}{ Actividad } & \multicolumn{1}{|c|}{ Contenido temático } & \multicolumn{1}{c|}{ Mensaje } & \multicolumn{1}{c|}{ Ficha técnica } \\
\hline $\begin{array}{l}\text { Artistas } \\
\text { tolimenses } \\
\text { (música, artes } \\
\text { plásticas y } \\
\text { visuales) }\end{array}$ & $\begin{array}{l}\text { Los participantes se relacionan } \\
\text { con los compositores de la re- } \\
\text { gión, que hacen parte del patri- } \\
\text { monio de la región del Tolima. }\end{array}$ & $\begin{array}{l}\text { ¿Quiénes son los artis- } \\
\text { tas más representativos } \\
\text { del Tolima? }\end{array}$ & $\begin{array}{l}\text { Sala con pantalla táctil } \\
\text { para navegación del } \\
\text { usuario. Contenidos } \\
\text { basados en videos, foto- } \\
\text { grafías, textos biográfi- } \\
\text { cos, narración y música. } \\
\text { Dispositivos de audio e } \\
\text { imagen. }\end{array}$ \\
\hline $\begin{array}{l}\text { Todos somos } \\
\text { musicales } \\
\text { (exposición } \\
\text { de } \\
\text { instrumentos } \\
\text { de percusión) }\end{array}$ & $\begin{array}{l}\text { Aires folclóricos del Tolima y la } \\
\text { región andina centro-sur. Rit- } \\
\text { mo, pulso y acento. } \\
\text { Instrumentos de percusión del } \\
\text { folclor musical tolimense. }\end{array}$ & $\begin{array}{l}\text { Cómo se interpretan los } \\
\text { instrumentos de percu- } \\
\text { sión de nuestra región. }\end{array}$ & $\begin{array}{l}\text { Espacio lúdico experi- } \\
\text { mental con instrumen- } \\
\text { tos musicales tradiciona- } \\
\text { les de percusión. } \\
\text { Se utilizan además } \\
\text { dispositivos como pan- } \\
\text { tallas, audio y tabletas } \\
\text { para guiar la actividad. }\end{array}$ \\
\hline
\end{tabular}




\begin{tabular}{|l|l|l|l|}
\hline \multicolumn{4}{|c|}{ Espacios externos } \\
\hline \multicolumn{1}{|c|}{ Actividad } & \multicolumn{1}{|c|}{ Contenido temático } & \multicolumn{1}{c|}{ Mensaje } & \multicolumn{1}{c|}{ Ficha técnica } \\
\hline $\begin{array}{l}\text { Muro } \\
\text { magnético }\end{array}$ & $\begin{array}{l}\text { Desarrollo del pensamiento } \\
\text { espacial, coordinación figu- } \\
\text { ra-fondo y construcción de } \\
\text { conocimientos, nociones, } \\
\text { conceptos geométricos y la } \\
\text { expresión artística. }\end{array}$ & $\begin{array}{l}\text { ¿Cuántas imágenes } \\
\text { puedes crear? }\end{array}$ & $\begin{array}{l}\text { Espacio mural lúdico experi- } \\
\text { mental de teselaciones con } \\
\text { figuras geométricas magné- } \\
\text { ticas. }\end{array}$ \\
\hline $\begin{array}{l}\text { Exposición } \\
\text { Tolima }\end{array}$ & $\begin{array}{l}\text { Exposición permanente de } \\
\text { fotografías sobre la historia } \\
\text { y patrimonio cultural del } \\
\text { Tolima. } \\
\text { Cabinas para escuchar gra- } \\
\text { baciones históricas sobre la } \\
\text { música. }\end{array}$ & $\begin{array}{l}\text { ¿Conoce la historia } \\
\text { del Tolima? }\end{array}$ & $\begin{array}{l}\text { Sala de exposición fotográfica } \\
\text { con dispositivos auditivos. Los } \\
\text { contenidos se renuevan perió- } \\
\text { dicamente. }\end{array}$ \\
\hline
\end{tabular}

\begin{tabular}{|c|c|c|c|}
\hline \multicolumn{4}{|c|}{ Talleres } \\
\hline Actividad & Contenido temático & Mensaje & Ficha técnica \\
\hline $\begin{array}{l}\text { Taller de } \\
\text { fotografía }\end{array}$ & $\begin{array}{l}\text { Técnicas básicas de fotogra- } \\
\text { fía. }\end{array}$ & $\begin{array}{l}\text { Qué se debe te- } \\
\text { ner en cuenta } \\
\text { para tomar una } \\
\text { fotografía. }\end{array}$ & $\begin{array}{l}\text { Laboratorio de práctica del } \\
\text { proceso técnico de la fotogra- } \\
\text { fía. Desarrolla temáticas alusi- } \\
\text { vas al Tolima. } \\
\text { Requiere equipo especializado } \\
\text { de fotografía y de digitaliza- } \\
\text { ción de imágenes. }\end{array}$ \\
\hline $\begin{array}{l}\text { Taller de danza } \\
\text { contemporánea } \\
\text { y danza } \\
\text { folclórica }\end{array}$ & $\begin{array}{l}\text { Pasos de los principales rit- } \\
\text { mos de las danzas típicas } \\
\text { tolimenses, pasos básicos de } \\
\text { géneros actuales. }\end{array}$ & $\begin{array}{l}\text { Danza, cuerpo y } \\
\text { vida. }\end{array}$ & $\begin{array}{l}\text { Actividad lúdica grupal orien- } \\
\text { tada por experto en danza. } \\
\text { Requiere espacio y elementos } \\
\text { de sonido adecuados a la ac- } \\
\text { tividad. }\end{array}$ \\
\hline Taller de grafiti & $\begin{array}{l}\text { Técnicas básicas de pintura. } \\
\text { Técnicas y uso de aerosoles } \\
\text { (aerosolgrafía). }\end{array}$ & $\begin{array}{l}\text { Cómo se hace un } \\
\text { grafiti. }\end{array}$ & $\begin{array}{l}\text { Actividad de muralismo en } \\
\text { espacio abierto. Requiere } \\
\text { orientación de un experto y } \\
\text { materiales de pintura aerosol. }\end{array}$ \\
\hline $\begin{array}{l}\text { Taller de } \\
\text { elaboración de } \\
\text { utensilios con } \\
\text { arcilla }\end{array}$ & Modelado y uso de la arcilla. & $\begin{array}{l}\text { Cómo se constru- } \\
\text { yen los utensilios } \\
\text { de cerámica. }\end{array}$ & $\begin{array}{l}\text { Actividad manual con ma- } \\
\text { terial moldeable. Requiere } \\
\text { herramienta, mobiliario y } \\
\text { equipos especializados de la } \\
\text { técnica de arcilla. }\end{array}$ \\
\hline $\begin{array}{l}\text { Concierto-taller } \\
\text { Didáctico }\end{array}$ & $\begin{array}{l}\text { Conciertos temáticos con } \\
\text { breves explicaciones sobre } \\
\text { los instrumentos utilizados } \\
\text { y contextualización de las } \\
\text { obras }\end{array}$ & $\begin{array}{l}\text { Música para to- } \\
\text { dos. }\end{array}$ & $\begin{array}{l}\text { Actividad artística musical en } \\
\text { vivo. Requiere espacio adecua- } \\
\text { do acústicamente y personal } \\
\text { encargado de las produccio- } \\
\text { nes artísticas. El programa se } \\
\text { renueva periódicamente. }\end{array}$ \\
\hline
\end{tabular}

Fuente: Hernández (2015). 
Tabla 3. Maleta didáctica y software

\begin{tabular}{|c|c|c|c|}
\hline \multicolumn{4}{|c|}{ Juegos de la maleta didáctica } \\
\hline Actividad & Descripción & Requerimientos técnicos & Cómo se juega \\
\hline $\begin{array}{l}\text { Kit de } \\
\text { construcción } \\
\text { de } \\
\text { instrumentos } \\
\text { musicales }\end{array}$ & $\begin{array}{l}\text { El usuario desarrolla habili- } \\
\text { dades de motricidad, en la } \\
\text { elaboración de instrumentos } \\
\text { musicales (lutería). } \\
\text { Acercamiento a la interpreta- } \\
\text { ción de dichos instrumentos } \\
\text { en su contexto musical. Se } \\
\text { ofrecen cinco prototipos de } \\
\text { instrumentos para armar con } \\
\text { sus respectivas partes, con } \\
\text { una guía de construcción. Se } \\
\text { realizan juegos relativos a la } \\
\text { interpretación de los instru- } \\
\text { mentos construidos. }\end{array}$ & $\begin{array}{l}\text { Materiales para el kit } \\
\text { de cinco instrumentos } \\
\text { tradicionales: chucho, } \\
\text { puerca, tambora, cien- } \\
\text { pies, zampoña. }\end{array}$ & $\begin{array}{l}\text { Sistema de armado mediante } \\
\text { guía ilustrativa y orientación de } \\
\text { profesor o guía experto. Prác- } \\
\text { tica musical de interpretación } \\
\text { con orientador. }\end{array}$ \\
\hline ¿Qué sabes? & $\begin{array}{l}\text { Juego de mesa, grupal, de } \\
\text { competencia mediante esca- } \\
\text { lera y tobogán representado } \\
\text { por un teclado de piano, } \\
\text { permite avanzar o retroceder } \\
\text { hacia una meta. }\end{array}$ & $\begin{array}{l}\text { Tablero de tela, reloj de } \\
\text { arena, dado, fichas. }\end{array}$ & $\begin{array}{l}\text { Los jugadores se rotan los tur- } \\
\text { nos mediante el azar de los } \\
\text { dados. Hacen actividades rela- } \\
\text { cionadas con música (pregun- } \\
\text { tas de habilidad, conocimiento, } \\
\text { audición); según sus logros } \\
\text { avanzan o retroceden. }\end{array}$ \\
\hline Zoótropo & $\begin{array}{l}\text { Mecanismo de ilusión óptica } \\
\text { basado en dibujos. }\end{array}$ & $\begin{array}{l}\text { Zoótropos, tiras de } \\
\text { papel, hojas, lápices, } \\
\text { borradores, plumones, } \\
\text { micropunta. }\end{array}$ & $\begin{array}{l}\text { Se parte de una idea preconce- } \\
\text { bida, se elaboran los dibujos, } \\
\text { se montan en el zoótropo y se } \\
\text { aprecia el resultado. }\end{array}$ \\
\hline $\begin{array}{l}\text { Formas del } \\
\text { sonido }\end{array}$ & $\begin{array}{l}\text { Creación de patrones de on- } \\
\text { das estacionarias formadas } \\
\text { por una sustancia granular } \\
\text { en una superficie plana; vi- } \\
\text { bración de la voz humana. }\end{array}$ & $\begin{array}{l}\text { Tarro, guantes, cartuli- } \\
\text { na, bandas de caucho, } \\
\text { bicarbonato de sodio, } \\
\text { tijera, cinta de enmas- } \\
\text { carar. }\end{array}$ & $\begin{array}{l}\text { Se construye el dispositivo y } \\
\text { mediante la voz se activan las } \\
\text { ondas sonoras produciendo las } \\
\text { figuras respectivas con los grá- } \\
\text { nulos de bicarbonato. }\end{array}$ \\
\hline $\begin{array}{l}\text { Reflectógrafo } \\
\text { (experiencias } \\
\text { de la imagen) }\end{array}$ & $\begin{array}{l}\text { Mecanismo de reflejo de } \\
\text { imágenes semitransparentes } \\
\text { para su reproducción me- } \\
\text { diante dibujo. }\end{array}$ & $\begin{array}{l}\text { Reflectógrafo, dibujos, } \\
\text { marcadores, instruc- } \\
\text { tivo. }\end{array}$ & $\begin{array}{l}\text { Se arma el reflectógrafo. Se } \\
\text { seleccionan los dibujos que se } \\
\text { van a reproducir. Se aplica el } \\
\text { mecanismo y se dibuja. }\end{array}$ \\
\hline $\begin{array}{l}\text { Perspectógrafo } \\
\text { (experiencias } \\
\text { de la imagen) }\end{array}$ & $\begin{array}{l}\text { Aparato compuesto de un } \\
\text { marco con vidrio y cuadrícula } \\
\text { centrada que permite ver en } \\
\text { perspectiva y dibujar sobre el } \\
\text { vidrio. }\end{array}$ & $\begin{array}{l}\text { Vidrio Sekurit, trípode, } \\
\text { papel, papel calcante, } \\
\text { lápices, lapiceros, mar- } \\
\text { cadores, alcohol, tela, } \\
\text { cinta de enmascarar. }\end{array}$ & $\begin{array}{l}\text { Se arma el dispositivo. Se dis- } \\
\text { tribuyen los materiales entre el } \\
\text { grupo participante. Se dibuja y } \\
\text { fija la imagen mediante trans- } \\
\text { ferencia. }\end{array}$ \\
\hline Papel modular & $\begin{array}{l}\text { Técnica de papel plegado } \\
\text { inspirado en el Origami, } \\
\text { basado en el principio de } \\
\text { modularidad (papiroflexia). } \\
\text { El usuario arma estructuras } \\
\text { geométricas por embalaje } \\
\text { de poliedros a partir de } \\
\text { plantillas impresas con imá- } \\
\text { genes relacionadas con la } \\
\text { historia y cultura del depar- } \\
\text { tamento del Tolima. }\end{array}$ & $\begin{array}{l}\text { Papel, patrones de } \\
\text { corte, instructivo, } \\
\text { regla, tijera, pegante, } \\
\text { plumones, lápices de } \\
\text { color. }\end{array}$ & $\begin{array}{l}\text { Se seleccionan los patrones } \\
\text { para armar. Se hacen los cor- } \\
\text { tes y el plegado del patrón. } \\
\text { Se arman las figuras. Permite } \\
\text { trabajo en grupo para crear } \\
\text { estructuras complejas. }\end{array}$ \\
\hline
\end{tabular}




\begin{tabular}{|c|c|c|c|}
\hline \multicolumn{4}{|c|}{ Software } \\
\hline Actividad & Descripción & $\begin{array}{c}\text { Requerimientos } \\
\text { técnicos }\end{array}$ & Cómo se juega \\
\hline $\begin{array}{l}\text { Escuchando al } \\
\text { Tolima }\end{array}$ & $\begin{array}{l}\text { Video descriptivo sobre } \\
\text { música tradicional del } \\
\text { Tolima. Incluye narra- } \\
\text { ción. }\end{array}$ & $\begin{array}{l}\text { Guion de video, au- } \\
\text { dios musicales, re- } \\
\text { gistro videográfico, } \\
\text { fotografía. }\end{array}$ & $\begin{array}{l}\text { Los usuarios pueden seleccionar } \\
\text { desde una galería de videos distin- } \\
\text { tos ejemplos musicales regionales. }\end{array}$ \\
\hline $\begin{array}{l}\text { Bailando con mi } \\
\text { Tolima }\end{array}$ & $\begin{array}{l}\text { Video descriptivo sobre } \\
\text { danzas tradicionales del } \\
\text { Tolima. Incluye narración } \\
\text { e ilustraciones de trajes } \\
\text { tradicionales. }\end{array}$ & $\begin{array}{l}\text { Guion de video, } \\
\text { audios musicales, } \\
\text { narración, registro } \\
\text { videográfico, foto- } \\
\text { grafía. }\end{array}$ & $\begin{array}{l}\text { Los usuarios pueden seleccionar } \\
\text { desde una galería de videos distin- } \\
\text { tos ejemplos de danzas y vestua- } \\
\text { rios regionales. }\end{array}$ \\
\hline $\begin{array}{l}\text { Músicos y } \\
\text { compositores del } \\
\text { Tolima }\end{array}$ & $\begin{array}{l}\text { Galería de videos, biogra- } \\
\text { fías, narración y ejemplos } \\
\text { musicales de siete músi- } \\
\text { cos y compositores toli- } \\
\text { menses representativos. }\end{array}$ & $\begin{array}{l}\text { Guion de video, au- } \\
\text { dios musicales, re- } \\
\text { gistro videográfico, } \\
\text { fotografía de archi- } \\
\text { vo, testimonios. }\end{array}$ & $\begin{array}{l}\text { Los usuarios pueden seleccionar } \\
\text { desde una galería de videos las } \\
\text { historias de personajes represen- } \\
\text { tativos de la música en el Tolima. }\end{array}$ \\
\hline $\begin{array}{l}\text { Instrumentos } \\
\text { musicales }\end{array}$ & $\begin{array}{l}\text { Ventana de videos ilustra- } \\
\text { tivos sobre la interpreta- } \\
\text { ción de los instrumentos } \\
\text { musicales de la orquesta. }\end{array}$ & $\begin{array}{l}\text { Guion de video, } \\
\text { audios musicales, } \\
\text { narración, registro } \\
\text { videográfico, foto- } \\
\text { grafía, hipervínculos. }\end{array}$ & $\begin{array}{l}\text { Los usuarios pueden seleccionar } \\
\text { desde una galería de videos e imá- } \\
\text { genes distintos ejemplos sobre la } \\
\text { interpretación de los instrumen- } \\
\text { tos de la orquesta. }\end{array}$ \\
\hline Paisaje sonoro & $\begin{array}{l}\text { Interfaz gráfica sonora } \\
\text { compuesta por una esce- } \\
\text { na y bibliotecas, sonidos } \\
\text { y figuras seleccionables } \\
\text { para crear asociaciones. }\end{array}$ & $\begin{array}{l}\text { Guion de contenido, } \\
\text { audios musicales, } \\
\text { narración, registro } \\
\text { videográfico, foto- } \\
\text { grafía, hipervínculos. }\end{array}$ & $\begin{array}{l}\text { Los usuarios pueden jugar a iden- } \\
\text { tificar y asociar escenas y sonidos } \\
\text { desde una galería gráfica. }\end{array}$ \\
\hline Tolima's Puzzle & $\begin{array}{l}\text { Rompecabezas basado en } \\
\text { el Tangram Chino usando } \\
\text { figuras precolombinas, } \\
\text { paisajes y temáticas de } \\
\text { las tradiciones tolimen- } \\
\text { ses. }\end{array}$ & No se especifican. & $\begin{array}{l}\text { Los usuarios pueden jugar a armar } \\
\text { rompecabezas y reconocer a tra- } \\
\text { vés de ellos iconografía precolom- } \\
\text { bina y elementos de parafernalia } \\
\text { tradicional tolimense. }\end{array}$ \\
\hline
\end{tabular}

\section{Diagnóstico}

Diseño de concepto-contenido: en cuanto a su concepto y contenido todas las actividades corresponden adecuadamente a los propósitos de interactividad dentro de seis grandes conceptos estratégicos:

1. Acústica y la música vista desde las tecnologías actuales.

2. Apropiación de patrimonio cultural e identidad regional tolimense.

3. Creatividad y pensamiento espacial, de interactividad para las artes plásticas, visuales y musicales.

4. Descubrimiento por experiencias de fenómenos de física sonora y de la imagen.

5. Reconocimiento de prácticas tradicionales de construcción de instrumentos (lutería).
6. Interactividad a partir de contenidos culturales regionales por medios informáticos.

No obstante lo anterior, en ninguna de las secciones se indican alternativas de renovación o actualización de contenidos para lo cual se requiere mayor investigación y documentación así como un enfoque más universal de tratamiento. La actividad de los instrumentos musicales, por ejemplo, debería ampliarse a los demás grupos de instrumentos que hacen parte de la región. Estos serán necesarios en el momento de hacer representaciones integrales del fenómeno cultural, por lo que se debe considerar que el público objetivo puede ser más diverso que el destinatario al local o regional.

Las propuestas Escuchando al Tolima, Bailando con mi Tolima, Músicos y compositores del Tolima e Instrumentos musicales están concebidas como más 
como videoclips que como aplicaciones o programas de software y no contemplan el uso de animaciones gráficas complementarias para su integración de contenidos. El concepto general de tipo expositivo informativo requiere un mayor desarrollo de las actividades y retos de conocimiento o lúdica para el usuario. Se recomienda delimitar sus enfoques o reestructurar solo dos propuestas: una entomusicológica y otra histórica. Las propuestas lúdicas y de aprendizaje deben definir claramente las actividades de interactividad del usuario. El software de instrumentos musicales está enfocado a la orquesta sinfónica, dejando por fuera el concepto universal de la música, por lo que se recomienda incorporar el concepto de músicas del mundo en su contenido o presentar el contexto histórico de la música universal a través de sus instrumentos. El Tangram requiere una mejor definición de sus contenidos temáticos considerando su concepto de armado de figuras con piezas lineales.

Para el taller de fotografía se debe considerar una referencia sobre su historia desde cómo se crea una fotografía análoga contrastada con la fotografía digital actual. El concierto taller requiere una programación que se renueve periódicamente. El taller de arcilla puede diversificarse además de utensilios, en réplicas de figuras precolombinas e instrumentos musicales como silbatos (ocarinas). El kit de instrumentos incluye como único instrumento melódico la zampoña que no pertenece al contexto cultural regional. Se recomienda su reemplazo por la flauta traversa prefabricada en material natural o sintético. Y la inclusión de la esterilla que sí hace parte del contexto y utiliza materiales naturales de fácil acceso. Se deben especificar las normas de seguridad para los juegos que utilizan herramientas y objetos de potencial riesgo en su montaje.

El juego, ¿qué es? Es una adaptación del juego Escaleras y serpientes pero no describe adecuadamente el contenido de la actividad ni es claro en su componente musical. No se recomienda su implementación. Los experimentos físicos sonoros y visuales requieren una mejor conceptualización del fenómeno que representan para ser comunicados al usuario. El proyecto de papiroflexia está planteado en un nivel muy básico y se recomienda su desarrollo dirigido a la experimentación de réplicas de figuras que combinen el plegado y el armado de piezas y definir temáticamente las líneas (arquitectura, monumentos, estatuaria precolombina, fauna), ampliando los modelos por niveles de complejidad.
El programa de las artes plásticas requiere una mejor delimitación para su implementación, en particular, el módulo de cine regional; para ello se recomienda contar con la consultoría del cineclub del Museo de Arte del Tolima o de la Universidad del Tolima para su perfeccionamiento. Se deben programar exposiciones temporales para rotar los contenidos de la sala Tolima Histórico.

Infraestructura: algunas actividades están diseñadas para máximo cinco usuarios y deberían plantearse alternativas para grupos grandes, además de especificar el aforo, inventario y localización del mobiliario por áreas y dotación de dispositivos por cantidad de usuarios esperados. Se debe considerar el área de reserva para la conservación, mantenimiento y rotación de obras, la zona de reserva para administración y mantenimiento de equipos y programas. Es recomendable establecer los espacios de trabajo y conservación de las maletas viajeras, según su destinación a instituciones educativas, bibliotecas o zonas rurales.

Planos: la propuesta requiere planos físicos y acústicos, entre ellos de 1) circulación, 2) iluminación, 3) instalaciones eléctricas, y 4) de dispositivos de audio y video. La instalación de dispositivos de audio para las salas debe corresponder a altas especificaciones y relación de equipamiento para su adecuado funcionamiento y aislamiento en relación con otras salas. Se requiere un plano de recorrido para las salas, teniendo en cuenta la disposición de obras, dispositivos de audio y video y mobiliario. La sala de instrumentos debe considerar el área de exposición diferenciada del área de prácticas. Para el taller de fotografía deben diferenciar sus áreas entre laboratorio y estudio con sus especificaciones de mobiliario y dispositivos. El taller de danza requiere planos y diseño para montaje de espejos, pisos en madera y sistema de audio ambiental. Se deben concebir los diseños de embalajes a partir de la imagen corporativa y estandarizar los planos de diseños de armado de los mecanismos de experimentos y del kit de instrumentos. Se recomienda el uso de pantallas personalizadas además de los elementos de infografía en las salas (véanse Museo del Caribe o Museo del Oro).

Seguridad: para todo el proyecto en su ejecución se deben especificar las condiciones de seguridad en salas. Algunos talleres experimentales deben considerar el uso de elementos de protección para los visitantes. Se deben establecer las normas de seguridad por el uso de herramientas. 
Infografía: la infografía requiere mayores referencias para implementar los contenidos, diferenciando entre 1) la infografía de salas, 2) los guiones para apoyo audiovisual, 3) el material impreso, y 4) el material promocional en redes y página web. Se debe elaborar una mejor infografía sobre el muro magnético (referente histórico de Escher) y diseñar o adquirir una mayor variedad de actividades dirigidas a la participación grupal. Hay que documentar y referenciar el contenido de todos los talleres para producir su infografía y sus respectivos materiales de apoyo como folletos y videoclips didácticos.

Es necesaria la infografía en los manuales de elaboración y uso como en las propuestas alternativas de uso didáctico de objetos e instrumentos de exhibición, así como en las maletas viajeras. En especial, se recomienda una mayor elaboración de contenidos explicativos de los fenómenos físicos representados adaptados para los distintos soportes de comunicación (guías impresas, CD tutoriales, web). Es indispensable producir infografías en otros idiomas para la página web y materiales impresos, así como es prioritario el diseño de ayudas alternativas para usuarios en condición de discapacidad.

Imágenes: el proyecto requiere un banco de imágenes propio que debe ser elaborado y registrado o, en su defecto, adquirido con los derechos de uso respectivo. Los materiales de imagen deben ser de alta resolución y debe gestionarse su adquisición con fondos patrimoniales históricos para uso del parque. En particular, son necesarios estos materiales para la exposición Tolima Histórico, el taller de fotografía y su edición en alta resolución debe pensarse para uso tanto impreso en gran formato como a través de medios audiovisuales. Es importante el diseño de diagramas o interfaz gráfica del software $y$ las animaciones 3D de objetos o contextos incorporados a este.

Audios: no se indica de qué manera se gestionan los archivos de audio requeridos para la propuesta de DJ, ni se informa cuáles serán sus fuentes, pero se debe considerar la adquisición de dichos materiales de audio o preferiblemente su creación con destino exclusivo para el proyecto. Se recomienda implementar el sistema de audioguía para el usuario. El paisaje sonoro requiere de software de audio especializado que permita la integración aleatoria de sonidos. En general, se requiere producir o adquirir material de audio de tres tipos: 1) música interpretada, 2) narraciones, y 3) ejemplos de ambientes sonoros de la naturaleza. El kit de instrumentos incluye actividades con música pero no se especifican sus fuentes ni mecanismos de reproducción. Para las salas patrimoniales sobre intérpretes y compositores, en lo posible, se debe considerar el uso de archivos sonoros originales preferiblemente de valor histórico (por ejemplo, Centro de Documentación Musical, Biblioteca Nacional, Archivo Sonoro de la Radio Nacional de Colombia, colecciones privadas de emisoras locales). Dentro de la producción de audioguías se debe considerar la opción bilingüe.

Video: para la propuesta de DJ se sugiere la implementación de un video como apoyo a la guía del usuario, que debe producirse con destino exclusivo al proyecto. Los talleres de fotografía, danza y grafiti requieren edición de videoclips para apoyo en soportes digitales. Para el concierto taller se sugiere el montaje de animaciones por hologramas en tamaño real (véase Museo del Caribe). La exposición Tolima Histórico requiere soporte audiovisual para guía por medios digitales en las cabinas.

Soporte técnico informático: se requiere una mayor especificidad en cuanto a los requerimientos informáticos para la puesta en marcha de las salas y dispositivos como consola de sonido, periféricos y biblioteca de música. Parte de los procesos instructivos de armado de piezas o demostraciones científicas de los fenómenos físicos pueden ser producidos por animaciones 3D para su reproducción desde computadores, dispositivos móviles o la web. Se recomienda el diseño de líneas de tiempo animadas por medio de software. Se deben especificar los programas o plataformas sobre los que correrá el software. Es preferible producir tutoriales audiovisuales sobre cada una de las actividades de las maletas que podrán incluirse en los kits o subirse a la web para su consulta. Los talleres de fotografía, arcilla y danza podrían contar con animaciones 3D de sus procesos.

Derecho de autor: se deben gestionar los derechos de propiedad intelectual del material audiovisual y musical producido originalmente por el proyecto y el trámite de permisos de uso de contenidos con derecho de autor. Se recomienda contar con el acompañamiento de una oficina jurídica de la entidad para gestionar el registro de licencias y patentes de otros materiales, dispositivos y software, fotografías, diseños gráficos, música o materiales educativos de otros autores que fueran requeridos en el proyecto. Los experimentos como el zoótropo, cimática, juego de mesa pueden tener versiones ya registradas en 
el mercado o en otras entidades como parques de ciencia, por lo que se recomienda producir materiales suficientemente originales para evitar plagios de patentes o, en caso de utilizar modelos protegidos, gestionar los derechos de uso. De no disponerse de obras de arte originales, se sugiere la adquisición de réplicas con autorización de uso.

El talento humano: la incorporación del talento humano idóneo y calificado es un componente sensible en el proyecto, por cuanto demanda de un equipo de investigadores y curadores para la renovación periódica de los contenidos. En consecuencia, el proyecto debe diseñar un programa e inducción para su personal, en especial, para la operación al público una vez estén en funcionamiento las salas, los talleres de experimentos y danza, así como los conciertos didácticos. Además del área administrativa, es necesario un equipo de expertos en diseño gráfico, animación 3D, ingenieros de sonido y programadores que garanticen el diseño de contenidos y su renovación periódica.

Otros: se recomienda la elaboración de réplicas a escala de los experimentos Vibramúsica y Muro Magnético y una mayor implementación del componente interactivo desde la producción de animaciones digitales y materiales informativos como $C D$, folletos explicativos, postales y juegos para su comercialización en la Tienda del Museo.

\section{Propuesta de rediseño de contenidos del área de arte y música}

A partir del diagnóstico de la primera fase de contenidos, se propone una nueva estructuración para el diseño de los contenidos y actividades de arte y cultura, a partir de los guiones museológico y museográfico (tablas 4 y 5 ).

Tabla 4. Estructura técnica del Parque Interactivo Aprociencia

\begin{tabular}{|c|c|}
\hline Contenidos & Criterios generales \\
\hline Textos & $\begin{array}{l}\text { Elaboración articulada del guion completo del centro. } \\
\text { Estandarización de fuentes, colores, logos en todas las piezas (murales, fichas, mó- } \\
\text { dulos, catálogos, página web). } \\
\text { Traducción a otros idiomas (inglés, francés) y braille. } \\
\text { Implementación de códigos QR. }\end{array}$ \\
\hline Imágenes & $\begin{array}{l}\text { Producción de imágenes en diferentes medios y resoluciones. } \\
\text { Registro de propiedad para adquisición de imágenes protegidas. } \\
\text { Desarrollo de la marca institucional en imágenes. }\end{array}$ \\
\hline Audios/videos & $\begin{array}{l}\text { Realización de material de audio propio en distintos formatos (wave, mp3, mp4) } \\
\text { legibles para distintas tecnologías. } \\
\text { Creación/gestión de bancos de archivos audiovisuales para edición. } \\
\text { Designación de unidad de medios (personal y equipos). } \\
\text { Plan de adquisiciones, elaboración y renovación de materiales audiovisuales. } \\
\text { Señalética: lenguaje de señas y para invidentes. } \\
\text { Realización de audioguías para el visitante. }\end{array}$ \\
\hline Planos & $\begin{array}{l}\text { Elaboración de planos arquitectónicos, guiones museográficos, maquetas, levanta- } \\
\text { mientos 3D. }\end{array}$ \\
\hline $\begin{array}{l}\text { Soporte técnico } \\
\text { informático }\end{array}$ & $\begin{array}{l}\text { Evaluación, presupuesto y adquisición de software licenciado. } \\
\text { Programa de innovación para diseño de software propio. } \\
\text { Capacitación al personal sobre el software del centro. } \\
\text { Programa de seguridad protección de datos. }\end{array}$ \\
\hline $\begin{array}{l}\text { Propiedad } \\
\text { intelectual }\end{array}$ & $\begin{array}{l}\text { Política de propiedad intelectual. } \\
\text { Registro de productos y materiales al DNDA. }\end{array}$ \\
\hline
\end{tabular}




\begin{tabular}{|c|c|}
\hline Contenidos & \multicolumn{1}{c|}{ Criterios generales } \\
\hline Tienda del Museo & $\begin{array}{l}\text { Reproducciones en afiches de las unidades y experimentos del Centro Aprociencia. } \\
\text { Camisetas, gorras, accesorios personales con la marca institucional. } \\
\text { Juegos y miniaturas de réplicas de las actividades del Centro Aprociencia. } \\
\text { Biblioteca, catálogos, postales relacionadas con las ciencias y artes del centro. }\end{array}$ \\
\hline
\end{tabular}

Fuente: el autor.

Tabla 5. Guiones museológico y museográfico del área de arte y música, Aprociencia

\begin{tabular}{|c|c|c|}
\hline \multicolumn{3}{|c|}{ Sala de Pensamiento } \\
\hline Actividad & Guion museológico & Guion museográfico \\
\hline \multirow{5}{*}{ 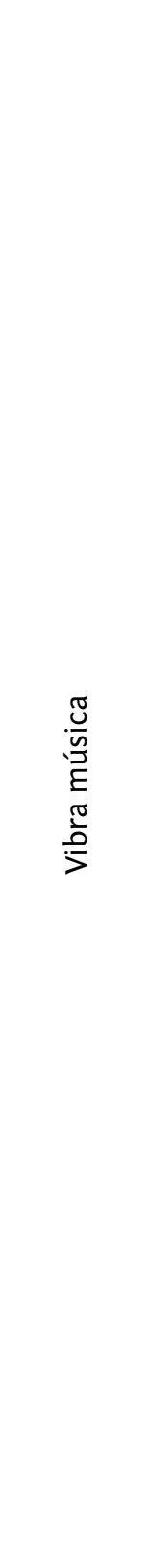 } & $\begin{array}{l}\text { Temas y subtemas } \\
\text { - El mundo de sonidos: la naturale- } \\
\text { za, la industria, la ciudad. } \\
\text { - Cada elemento vibrante produce } \\
\text { una sensación que nuestro oído } \\
\text { convierte en sonido. } \\
\text { - El material sonoro constituye la } \\
\text { base fundamental de la música. } \\
\text { - Concepto de acústica asociado a la } \\
\text { música y la física. }\end{array}$ & $\begin{array}{l}\text { Textos } \\
\text { - Murales en títulos (encabezado de sala) y párrafos } \\
\text { de la biografía de Ernst Chladni (1809). } \\
\text { - Descripciones del fenómeno observado. Palabras } \\
\text { clave. Cédulas de objetos. } \\
\text { - Señalética de seguridad. Instructivos para el usua- } \\
\text { rio. Texto alterno en inglés. }\end{array}$ \\
\hline & $\begin{array}{l}\text { Contenido } \\
\text { - Las vibraciones que capta el oído } \\
\text { son la base para esta actividad en } \\
\text { la que se observa el fenómeno fí- } \\
\text { sico de las ondas sonoras mecáni- } \\
\text { cas representadas con materiales } \\
\text { como arena, sal y aceite. } \\
\text { - La música está compuesta por on- } \\
\text { das sonoras y estas pueden repre- } \\
\text { sentarse en diversos materiales. }\end{array}$ & $\begin{array}{l}\text { Objetos } \\
\text { - Generador de ondas. } \\
\text { - Material granular. } \\
\text { - Placas vibrantes. } \\
\text { - Recipiente con líquido. } \\
\text { - Versión análoga del experimento (opcional). } \\
\text { - Arco de violín (opcional). }\end{array}$ \\
\hline & $\begin{array}{l}\text { Material expositivo } \\
\text { - Textos murales. } \\
\text { - Dispositivo del experimento. } \\
\text { - Versión análoga del dispositivo } \\
\text { (opcional). }\end{array}$ & $\begin{array}{l}\text { Mobiliario } \\
\text { - El módulo del dispositivo cuenta con una base y } \\
\text { con mecanismos de seguridad y protección para el } \\
\text { usuario. } \\
\text { - Conexiones eléctricas ocultas. }\end{array}$ \\
\hline & $\begin{array}{l}\text { Apoyos } \\
\text { - Animación digital del fenómeno } \\
\text { (video). } \\
\text { - Lenguaje de señas. } \\
\text { - Audioguía. }\end{array}$ & $\begin{array}{l}\text { Imágenes y audiovisuales } \\
\text { - Fotos de Chladni y científicos relacionados. Se } \\
\text { podrá comparar el fenómeno análogo como el del } \\
\text { dispositivo mediante animación digital en pantalla } \\
\text { o en directo. } \\
\text { - Diagramas de las ondas (versiones originales } \\
\text { Chladni). Fórmulas físicas. }\end{array}$ \\
\hline & $\begin{array}{l}\text { Otros } \\
\text { Un personal de guía orienta la ac- } \\
\text { tividad y supervisa la manipulación } \\
\text { preventivamente. }\end{array}$ & $\begin{array}{l}\text { Área de exposición (sala múltiple) } \\
\text { - El dispositivo se encuentra ubicado de tal manera } \\
\text { que los usuarios puedan ser observados por otros } \\
\text { visitantes mientras participan. } \\
\text { - Se debe diferenciar la zona de circulación y transi- } \\
\text { ción a otras actividades de la misma sala. }\end{array}$ \\
\hline
\end{tabular}




\begin{tabular}{|c|c|c|}
\hline Actividad & Guion museológico & Guion museográfico \\
\hline \multirow{5}{*}{ 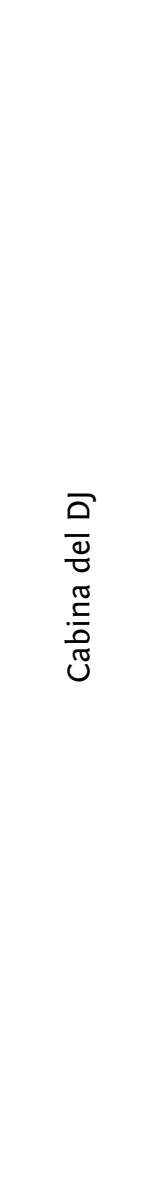 } & $\begin{array}{l}\text { Temas y subtemas } \\
\text { Los DJ (disc jockey) ponen música y mezclan } \\
\text { sonidos grabados o digitalizados para la } \\
\text { radio, producción musical o creación mu- } \\
\text { sical. Los usuarios podrán usar diferentes } \\
\text { técnicas del DJ como el groove, el breakbeat } \\
\text { y el remix. }\end{array}$ & $\begin{array}{l}\text { Textos } \\
\text { Murales: título de actividad. Relatos de la } \\
\text { historia de los disc jockey. Líneas de tiempo. } \\
\text { Palabras clave, nombres de estilos propios } \\
\text { del género, cédulas en dispositivos. }\end{array}$ \\
\hline & $\begin{array}{l}\text { Contenido } \\
\text { Cómo se hace una mezcla de música en la } \\
\text { radio. } \\
\text { Qué dispositivos se utilizan y cómo funcio- } \\
\text { nan. } \\
\text { Actividad experimental sonora. }\end{array}$ & $\begin{array}{l}\text { Objetos } \\
\text { Mesa de mezclas. } \\
\text { Sistema de parlantes. } \\
\text { Audífonos. } \\
\text { Ryder de luces móviles. } \\
\text { Avisos luminosos. }\end{array}$ \\
\hline & $\begin{array}{l}\text { Material expositivo } \\
\text { Textos murales. } \\
\text { Fotos de DJ famosos. } \\
\text { Mesa de mezcla de DJ. }\end{array}$ & $\begin{array}{l}\text { Mobiliario } \\
\text { Módulos para instalación de mesa de mezcla. } \\
\text { Soportes o anclajes para cabinas y luces. } \\
\text { Tarimas y barras separadoras entre el disc } \\
\text { jockey y el público. }\end{array}$ \\
\hline & $\begin{array}{l}\text { Apoyos } \\
\text { Música, bancos de sonidos del dispositivo. } \\
\text { Animaciones, efectos visuales. }\end{array}$ & $\begin{array}{l}\text { Imágenes y audiovisuales } \\
\text { Fotos de disc jockey famosos. } \\
\text { Fotos vintage de discotecas famosas del mundo. } \\
\text { Figuras holográficas sincronizadas con la } \\
\text { música en pantallas de televisión (opcional). }\end{array}$ \\
\hline & $\begin{array}{l}\text { Otros } \\
\text { Un personal de guía animador. Actividad de } \\
\text { grupo con participación del público. Vestua- } \\
\text { rio sugestivo para el usuario. Fotografía de } \\
\text { colección (selfies grupales). }\end{array}$ & $\begin{array}{l}\text { Área de exposición } \\
\text { Sala múltiple. Aforo: hasta } 30 \text { personas. }\end{array}$ \\
\hline
\end{tabular}

\begin{tabular}{|c|c|c|}
\hline \multicolumn{3}{|c|}{ Sala de la Cultura Tolimense } \\
\hline Actividad & Guion museológico & Guion museográfico \\
\hline \multirow[t]{3}{*}{$\begin{array}{l}\text { Galería de } \\
\text { artistas } \\
\text { tolimen- } \\
\text { ses (artes } \\
\text { plásticas y } \\
\text { visuales) }\end{array}$} & $\begin{array}{l}\text { Temas y subtemas } \\
\text { Conocer los principales representantes de las } \\
\text { artes en el Tolima. } \\
\text { Identificar los momentos y las obras desta- } \\
\text { cadas de las artes plásticas visuales y sono- } \\
\text { ras del Tolima. }\end{array}$ & $\begin{array}{l}\text { Textos } \\
\text { Microbiografías, líneas de tiempo. }\end{array}$ \\
\hline & $\begin{array}{l}\text { Contenido } \\
\text { Quiénes son los artistas destacados en la } \\
\text { música tolimense. } \\
\text { Qué artistas plásticos y obras representan la } \\
\text { región. } \\
\text { Cuál ha sido la historia de las artes visuales } \\
\text { en el Tolima. }\end{array}$ & $\begin{array}{l}\text { Objetos } \\
\text { Réplicas y materiales de práctica para uso } \\
\text { del visitante. }\end{array}$ \\
\hline & $\begin{array}{l}\text { Material expositivo } \\
\text { Pantallas táctiles. } \\
\text { Textos murales. } \\
\text { Fotos de personajes. } \\
\text { Obras de arte pictórico (réplicas). }\end{array}$ & $\begin{array}{l}\text { Mobiliario } \\
\text { Urnas. } \\
\text { Cubos de exposición. } \\
\text { Bastidores. } \\
\text { Paneles. } \\
\text { Bancas de descanso. }\end{array}$ \\
\hline
\end{tabular}




\begin{tabular}{|c|c|c|}
\hline \multicolumn{3}{|c|}{ Sala de la Cultura Tolimense } \\
\hline Actividad & Guion museológico & Guion museográfico \\
\hline \multirow{2}{*}{$\begin{array}{l}\text { Galería de } \\
\text { artistas toli- } \\
\text { menses (ar- } \\
\text { tes plásticas } \\
\text { y visuales) }\end{array}$} & $\begin{array}{l}\text { Apoyos } \\
\text { Personal guía. } \\
\text { Audioguía. }\end{array}$ & $\begin{array}{l}\text { Imágenes y audiovisuales } \\
\text { Fotos murales, videoclips en pantallas } \\
\text { personalizadas o de gran formato. }\end{array}$ \\
\hline & $\begin{array}{l}\text { Otros } \\
\text { Control de iluminación y ambiental de tempe- } \\
\text { ratura y ventilación. }\end{array}$ & $\begin{array}{l}\text { Área de exposición } \\
\text { Señalética. }\end{array}$ \\
\hline \multirow{5}{*}{$\begin{array}{l}\text { Música para } \\
\text { los sentidos } \\
\text { (antes todos } \\
\text { somos musi- } \\
\text { cales). } \\
\text { (Una explo- } \\
\text { sión de ritmo } \\
\text { y percusión) }\end{array}$} & $\begin{array}{l}\text { Temas y subtemas } \\
\text { Espacio lúdico-experimental con instrumentos } \\
\text { musicales tradicionales de percusión. } \\
\text { Folclor musical tolimense y otras regiones de } \\
\text { Colombia. }\end{array}$ & $\begin{array}{l}\text { Textos } \\
\text { Murales (títulos de la sala). Descripcio- } \\
\text { nes de animación para el participante. } \\
\text { Tarjetones explicativos para los partici- } \\
\text { pantes. Cédulas de instrumentos. }\end{array}$ \\
\hline & $\begin{array}{l}\text { Contenido } \\
\text { Aires típicos de las fiestas del Tolima y la re- } \\
\text { gión andina centro-sur. } \\
\text { Ritmo, pulso y acento. }\end{array}$ & $\begin{array}{l}\text { Objetos } \\
\text { Juegos de instrumentos de percusión: } \\
\text { tambores, placas, sonajas. } \\
\text { Instrumentos de apoyo melódico armó- } \\
\text { nico: clarinete, flauta, tiple. }\end{array}$ \\
\hline & $\begin{array}{l}\text { Material expositivo } \\
\text { Textos murales. } \\
\text { Instrumentos musicales de percusión y acce- } \\
\text { sorios. } \\
\text { Proyecciones de músicos y conjuntos tradicio- } \\
\text { nales. }\end{array}$ & $\begin{array}{l}\text { Mobiliario } \\
\text { Disposición circular de cojines y bases } \\
\text { para los usuarios. } \\
\text { Módulo móvil para el almacenamiento } \\
\text { y distribución de los instrumentos. } \\
\text { Tarima central para el guía de la actividad. } \\
\text { Amplificación de sonido. }\end{array}$ \\
\hline & $\begin{array}{l}\text { Apoyos } \\
\text { Se utilizan, además, dispositivos como pan- } \\
\text { tallas, audio y tabletas para guiar e ilustrar la } \\
\text { actividad. } \\
\text { Banco de sonidos pregrabados. } \\
\text { Tapetes, cojines o bases para sentarse. } \\
\text { Amplificación de sonido para el guía. }\end{array}$ & $\begin{array}{l}\text { Imágenes y audiovisuales } \\
\text { Reproducciones digitales de los instru- } \\
\text { mentos. } \\
\text { Animaciones holográficas en muros en } \\
\text { el tamaño real de los músicos tocando. } \\
\text { Códigos QR para reproducir instrumen- } \\
\text { tos virtuales en dispositivos móviles. }\end{array}$ \\
\hline & $\begin{array}{l}\text { Otros } \\
\text { Dos personales de guía para conducir la ac- } \\
\text { tividad. Se realiza por sesiones de tiempo } \\
\text { establecido que se repiten cada hora. Los par- } \\
\text { ticipantes deben tomar la actividad en grupos } \\
\text { según turno. } \\
\text { Opcionalmente se puede implementar una } \\
\text { versión experimental con dispositivos móviles. } \\
\text { Registro de videos y fotos de colección de par- } \\
\text { ticipantes. }\end{array}$ & $\begin{array}{l}\text { Área de exposición } \\
\text { Sala independiente tipo circular con } \\
\text { capacidad para veinte participantes y } \\
\text { público observador externo. }\end{array}$ \\
\hline
\end{tabular}

Fuente: el autor.

\section{Programas de implementación}

De acuerdo con el modelo propuesto para el diagnóstico y el plan de implementación del proyecto Aprociencia, se enuncia la metodología de programas que permite la puesta en marcha de manera estructurada de cada uno de los procesos macro del proyecto.
- Programa institucional: define el tipo de entidad responsable del proyecto según su constitución jurídica y sus funciones administrativas. Puede ser pública, privada, mixta, universitaria y, de acuerdo con ella, podrá establecer sus compromisos con la ejecución y administración de la entidad museal o centro de ciencia. 
- Programa de colecciones: define los inventarios de la totalidad de las piezas, prototipos, obras de arte $o$ artefactos que constituyen el objeto de exposición al público. Desde este programa se establecen las políticas de incremento, documentación, investigación y conservación de las colecciones. Cuando son entidades universitarias se articulan diferentes facultades y grupos de investigación en torno a temas afines desde la ejecución del proyecto.

- Programa arquitectónico: este programa se encarga de orientar y asesorar las decisiones referentes a la planta física del proyecto y la distribución de áreas e instalaciones requeridas para su funcionamiento y permanente actualización.

- Programa de exposición: corresponde al equipo de expertos curadores y diseñadores que establece los contenidos museológicos y museográficos, en alianza con el equipo de informática y arquitectura.

- Programa de difusión y comunicación: establece las estrategias para llegar a los diferentes públicos tanto dentro del centro de la ciencia como hacia la comunidad local, nacional e internacional. Define la generación de productos de divulgación y la realización de eventos promocionales para el fortalecimiento de la misión institucional del proyecto en la formación de públicos.

- Programa de seguridad: define las acciones y estrategias que conducen a garantizar la seguridad tanto física como de propiedad intelectual del proyecto. Define políticas de protección de planta física y mobiliario, normas de seguridad para personal operario y para el público, política de pólizas y seguros de riesgo, licencias y patentes de propiedad por uso de contenidos y materiales protegidos.

- Programa de recursos humanos: establece y gestiona los perfiles y funciones de recurso humano necesario para la puesta en marcha del proyecto. De común acuerdo con las distintas áreas del centro de ciencia o museo, define programas de vinculación y capacitación para el personal técnico, científico y operativo del proyecto.

- Programa económico: establece las estrategias de gestión, administración y sostenibilidad financiera del proyecto. Hace gestión de convenios interinstitucionales para el aprovechamiento estratégico de recursos de financiamientos públicos y privados, así como para la generación de productos de mercadeo derivados de las actividades del centro como Tienda del Museo, ferias y eventos académicos, certámenes y actividades culturales.

\section{Conclusiones}

La evolución del conocimiento científico e histórico universal ha necesitado desde siempre de entornos para socializar y compartir sus logros con el público no especializado, y para ello se han creado los museos y centros de ciencia que por sus características de origen, financiamiento y cobertura pueden impactar de manera lúdica en una comunidad, al abrir una ventana al patrimonio cultural y científico. La democratización del conocimiento es uno de los fenómenos más importantes del siglo xxı plasmado en el surgimiento e innovación de entidades museales y de ciencia que cada vez alcanzan un mayor grado de incidencia en la formación de públicos, gracias a su innovación y a la práctica de experiencias colaborativas en red. La existencia de entidades como el ICOM, que regula y acompaña este tipo de iniciativas es garante de la protección del patrimonio que se conserva y difunde con estos proyectos.

Colombia cuenta con iniciativas en la creación de parques tecnológicos y centros de ciencia que permiten convalidar nuevas iniciativas en el ámbito regional, focalizadas a valores patrimoniales particulares y diferenciadores. Para el Tolima, el papel que han desempeñado las instituciones de educación superior como la Universidad del Tolima, liderando iniciativas de apropiación social de conocimiento, han sido significativas para el proyecto Aprociencia, el cual no tiene otro antecedente en la región. Así mismo, las experiencias formativas y de construcción de identidad musical de Ibagué han sido un referente que actualmente permea todo el departamento $y$ encuentra resonancia en iniciativas cultural y científico como las que se proponen en este proyecto.

En su primera fase, Aprociencia ha formulado un grupo de contenidos y propuestas de diseño de recursos en arte y música, para su implementación en la creación del parque tecnológico que lleva su nombre. Cada uno de sus componentes fueron analizados a partir de modelos internacionales aplicables a proyectos museales de cuarta generación como el 
que se propone aquí. Las características particulares del componente de arte y música suponen la intervención de procedimientos técnicos y tecnológicos acordes con los estándares y a la normatividad actuales que garanticen su inclusión dentro de la red de entidades de este tipo a escalas nacional e internacional. Es pertinente que se incorporen acciones propias del sector museal y de centros de ciencias con experiencia en nuestro país y de Latinoamérica, mediante alianzas estratégicas que potencialicen sus objetivos. A escala regional son importantes las gestiones en políticas de ciencia y tecnología, en particular, para canalizar alianzas con programas como Tolima Vive Digital que tienen despliegue en municipios del departamento y comparten su misión. Desde el punto de vista académico, se requiere respaldar el proyecto en un equipo de expertos que generen contenidos y nuevo conocimiento, mediante la creación de laboratorios, centros de documentación y grupos de investigación transdisciplinar con capacidad de actuar en redes científicas afines al proyecto.

\section{Referencias}

Braendholt, I. y Thorek, J. (2013). Social learning spaces and knowledge producing processes. Denmark: Danish Agency for Culture.

Casalins, D. y Miranda, T. (2012). El museo del Caribe, un laboratorio para la primera infancia. Revista Arte \& Diseño, 10 (2), pp. 53-60. Recuperado de http://www.uac.edu.co/images/ stories/publicaciones/revistas_cientificas/ arteydiseno/vol umen-10-no-2/art_10.pdf

Chladni, E. F. E. (1809). Treatise on acoustics, Robert T. Beyer (trad.). Basel: Springer International Publishing.

Economou, M. (2004). Evaluation strategies in the cultural sector: The case of the Kelvingrove Museum and Art Gallery in Glasgow. Museum and Society, 2(1), 30-46.

Departamento Nacional de Planeación. (2008). Política nacional de competitividad y productividad. Documento Conpes 3527. Bogotá: Departamento Nacional de Planeación.

Galindo, H. (2003). Estudio y catalogación de la colección de instrumentos musicales Alfonso Viña Calderón. Ibagué: Ceres, Coruniversitaria.
Galindo, H. (2009). Instrumentarium. Las culturas tradicionales vistas desde el patrimonio musical instrumental. Música, Cultura y Pensamiento, 1(1), pp.99-111. Ibagué: Conservatorio del Tolima.

Hernández, A. (2015). Informe de junio del 2015. Implementación de una estrategia de apropiación social del conocimiento basada en innovación para la infancia, la adolescencia y la juventud del departamento del Tolima. Ibagué: Universidad del Tolima.

International Council of Museums (ICOM). (2013). Código de Deontología del ICOM para los museos. Recuperado de http://icom.museum/fileadmin/user_upload/pdf/Codes/ code_ethics2013_es.pdf.

Lannes, P. (2015). El futuro de los museos es la Educación. III Encuentro Nacional \& II Internacional de Comunidades Académicas. Red Universitaria Metropolitana de Bogotá, Bogotá.

López, A. (s. f.). Política de Museos. Ministerio de Cultura de Colombia. Recuperado de http:// www.museoscolombianos.gov.co/fortalecimiento/comunicaciones/publicaciones/Documents/politicamuseos.pdf.

Lozano, M. (2005). Programas y experiencias en popularización de la ciencia y la tecnología. Panorámica desde los países del Convenio Andrés Bello (p. 160). Bogotá: Convenio Andrés Bello.

Ministerio de Educación, Cultura y Deporte de España (s. f.). Plan Museal. Recuperado de http:// www.mecd.gob.es/cultura-mecd/areas-cultura/museos/mc/pm/pm/presentaciones. html.

Ministerio de Cultura de Colombia. Sistema de Información Museos de Colombia (Simco). Recuperado de http://simco.museoscolombianos.gov.co/InicioSesion?ReturnUrl=\%2f.

Ministerio de Cultura de Colombia. (2014). La conservación de las colecciones. Recuperado de http://www.museoscolombianos.gov.co/ publicaciones/cartillas/inventario_2014.pdf

Ministerio de Cultura de Colombia. (2014) El inventario de las colecciones. [En línea] Recuperado de http://www.museoscolombianos.gov.co/ publicaciones/cartillas/conservacion_2014. pdf 
McManus, P. (1992). Topics in museums and science education. Studies in Science Education, 20, 157-182. Recuperado de http://www.tandfonline.com/toc/rsse20/current.

Sistema de Patrimonio Cultural y Museos. (2007). Memoria del Museo de la Ciencia y el Juego. Bogotá: Universidad Nacional de Colombia. Recuperado de http://www.bdigital.unal. edu.co/5943/1/sistemapatrimonioculturalymuseos.20073.pdf.

Pardo, C. O. (1997). Historia de una hazaña. Ibagué: Pijao.

Rebolledo, B. F. (2015, junio). "Sama-Sama": un viaje mágico a través de la música, el ritmo y el movimiento. ABC. Recuperado de http:// www.abc.es/madrid/20150603/abci-sama-sama-estreno-201506021658.html.
Reynoso, E., Sánchez Mora, C. y Tagüeña, J. (2005). Lo "glocal", nueva perspectiva para desarrollar museos de ciencia. Elementos: Ciencia y Cultura, 12(059). 33-41. Puebla: Benemérita Universidad Autónoma de Puebla. Recuperado de http://www.redalyc.org/pdf/ 294/29405906.pdf

Tagüeña, J., Sánchez, C. y Reynoso, E. (2006). El museo "glocal" y sus audiencias. En Museos universitarios (pp. 129-140). Berlín: Universidad de Humboldt.

Villegas, H. (1962). Reseña histórica del Conservatorio del Tolima. Ibagué: Contraloría General del Departamento. 


\section{Contenido}

VOL. VII N.o 7 - Enero 2018

4 resemancen

\section{Música y Cultura}

Ruana y carranga: dos símbolos campesinos de origen múltiple Leonardo Zambrano Rodríguez

\section{Música y pensamiento}

18 Arte y música como apropiación social del conocimiento en el proyecto regional Aprociencia Humberto Galindo Palma

36

La evaluación formativa desde la concepción de Phillipe Perrenoud: una experiencia en la clase de Historia de la Música Boris Alfonso Salinas Arias

\section{Música en clave}

48

Creación de herramientas de análisis para

el estudio del contrapunto tonal: una aproximación desde la música popular María Cristina Vivas Barrera, Adrián Camilo Ramírez Méndez, Juan Gabriel Alarcón (colaborador)

(1) Tiple solista en Colombia:

Sergio Andrés Camero Tierradentro, Jorge Iván Ramírez Marín, Yordi Andrey Vargas Guzmán

\section{Separata}

Niebla de Chipre para orquesta de cuerdas segundo premio en el Concurso Internacional de Composición "Música Jove",

Valencia-España 2016

Andrés A. Garzón Charry

Convocatoria Revista No. 8

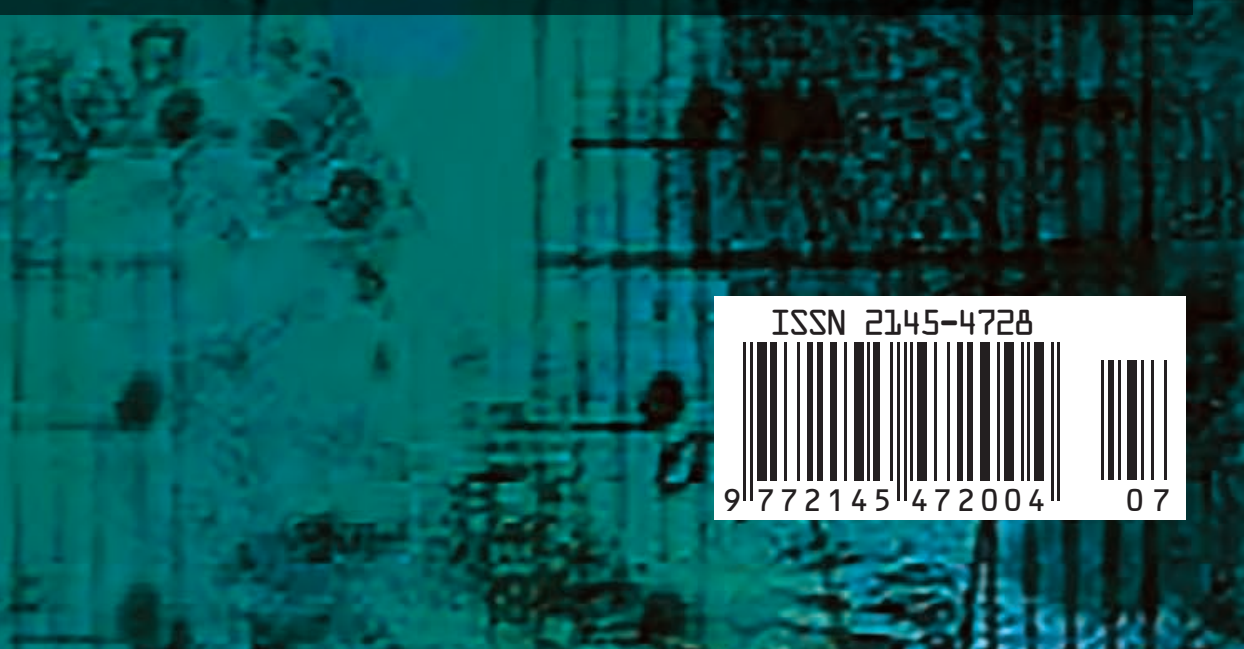

